SHS Web of Conferences 14, 02013 (2015)

DOI: $10.1051 /$ shsconf/20151402013

(C) Owned by the authors, published by EDP Sciences, 2015

\title{
Popular Music in Singapore: Cultural Interactions and the "Inauthenticity" of Singaporean Music
}

\author{
Lequn $\mathrm{Fu}$ \\ School of Communication, Zhejiang University City College, 310015 Hangzhou Zhejiang, China
}

\begin{abstract}
The popular music industry in Singapore advocates for Western music as being superior to local Singaporean music. Singaporeans are usually skeptical about the quality of Singaporean musicians, because of the "inauthentic" stereotype of Singaporean music. So this paper analyses the culture interaction and Singapore music from some current phenomenon that J-pop, K-pop and other music types become an integral part of music culture in Singapore. At the same time, this paper elaborates Authenticity and its importance in Singaporean music and media industry and its influences.
\end{abstract}

Keywords. popular music; Singapore; cultural interactions; inauthentic

\section{Introduction}

Kong (1995) notes that "Singaporean popular music has represented a distinctively Singaporean spirit and identity" (p. 60). Musical lyrics from a specific area can convey images of the place, and a large number of English, Malay, and Chinese songs exist in Singapore. Singaporeans judge the quality of musicians on their perceived authenticity. Nowadays, Singaporean audiences tend to consume Western music and give little support to local musicians because Singaporean musicians are always perceived as inauthentic: "The post-colonial modernities are not only localized modernities from the perspective of cultural producers, but also 'inauthentic modernities' from the perception of cultural consumers" (Matter, 2009, p. 180). The popular music industry in Singapore advocates for Western music as being superior to local Singaporean music. In addition, Singaporeans are usually skeptical about the quality of Singaporean musicians, because of the "inauthentic" stereotype of Singaporean music.

\section{Culture interactions and Singapore music}

Singapore music appears to have originated with influences from Malay, China, Indonesia and some other Asian countries. In addition, Singaporean popular music is essentially western-based music combined with some local elements, such as Singlish, Chinese culture, Malay culture, patriotism and so on. It is quite different from other countries, which have their own music genre and traditional music. Singapore doesn't have a specific type of music which could fill people with national pride.
Singapore has a huge music market, and its music industry can be seen as a flourishing hub of the Asia-Pacific region. Singaporean music is usually presented in English, Malay, or Chinese. Many music genres are developing constantly and are being accepted by the local people, such as J-pop, K-pop, hip-pop, punk, and so on. In addition, every genre of music has interacted with each other, which has made the entire music industry in Singapore more creative and enjoyable. For example, Singapore is one of the hubs of J-pop music. As Ng (2003) noted, "Jpop has become an integral part of music culture in Singapore." (p. 11)

After World War II, pop music began to flourish in Singapore from the influence of Western countries. Both the radio and LP record were used to promote music products, especially music from Western countries. As a result, popular music began to thrive, due to the flourishing western music culture in Singapore. The entire population of Singapore received a certain amount of influence from Western music culture: "The influence of Americanization and the process of cultural imperialism lead to both economic and culture dominance" (Kong, 1995, p61). This is quite similar to the situation of South Korea. Jin and Ryoo (2012) noted that Korean music started to grow after the Cold War by the influence of American forces, which transmitted American popular music extensively throughout South Korea. The local music of South Korea had been changed by the influence of Americanization. Singapore has a similar background and history to South Korea-the entire music industry of Singapore tends to accept Western music, and modern, local musicians tend to create songs that have a "Western" identity, in order to be more accepted by locals and have the chance to become popular in Singapore. 
In terms of the Singaporean music market, Singapore is an important center of the Asia-Pacific region and has huge visible and potential market values. Each genre of music has its own market and target audience. To a certain degree, the audience groups behind each genre of music reflect Singaporean society and the groups of people that each music genre wants to represent. For instance, hip-hop music in Singapore mainly targets Indian people, who think that their social and cultural position is quite similar to those of African Americans (Mattar, 2007). In addition, Malays are addicted to rock and metal music, and dance music often targets Chinese youth. These facts demonstrate the multicultural society of Singapore, as well as the integrated, syncretic characteristics of the music industry.

According to Kong (1995), "mainstream and independent musicians are the two main groups of contemporary musicians in Singapore." (p 55)Mainstream musicians usually have contract with record labels, and their songs are usually not written by the artists themselves. The lyrics usually focus on the topics of love and romance, in order to target young people. Another group of mainstream musicians write songs for themselves and normally inject their own identity and sense of life into their songs (such as humor, Singaporean culture, and their personal life). Independent musicians usually manage their music work by themselves, without the help of record labels, because normally they perform in the pub or on the street. Most independent musicians in Singapore operate as bands or buskers. They have the creative space to create songs without thinking about their target audiences or demands of the music market. Their musical styles and lyrics are usually more diverse than those of mainstream musicians; they may be punk, thrash metal, cyberpunk, death metal, and so on.

Popular music can be regarded as a type of cultural good. Singapore is a multicultural country that includes a variety of cultures, such as the Chinese, Indian, Malay, and Western cultures. These different cultures comprise the domestic music industry of Singapore. It is not hard to find the Singaporean culture, spirit, and identity through the local music market, and the use of different languages or cultures in music presents the multicultural society of Singapore. English pop music in Singapore highlights this cultural diversity; for example, most of Dick Lee's songs involve elements of Malay, Chinese, and Indian culture. One of his songs includes many Malay words and phrases, "such as 'salah,' which means "mistake" in English, and "bodoh," [which] means 'silly person" (Kong, 1995). It is quite similar with the situation in South Korea, English language is quite popular in producing Korean songs. As Jin and Ryoo (2012) note that "it is not easy to use Korean for simple chorus and melody lines." (p. 8) In addition, young people in Korea are passionate about Korean-English songs. As a result, there are a lot of Korean musicians (such as: Big Bang and Se7en) who produce Korean-English songs become more popular.

Peranakan folk music is the most popular form of Singaporean music. It combines English lyrics with Malay tunes. Singaporean musicians nowadays also apply Peranakan culture to contemporary tunes. For example, there is a song called "Rasa Sayang" from one of the most famous Singaporean singers, Dick Lee. The melody of this song completely uses Malay music and tunes, but the lyrics are in English. Another song called "Mustapha" by Dick Lee has an Indian tune but lyrics in Mandarin, Tamil, and English. It represents the multicultural situation of Singapore and the identity of the Singaporean people.

\section{Authenticity and its importance in Singaporean music}

Peterson (2005) says that "authenticity is socially constructed and authenticity is implicitly a polemical concept." (p 1086) In the case of Singaporean music, its inauthenticity has been constructed by the attitude and values of society. Social phenomena have constructed this "inauthenticity" context. Singaporean music itself does not relate to "inauthenticity," yet society has labeled this type of music: "Consumers also play as an important role in judging some 'non-urban' musical forms [such as blues, folk music, and country music]" (Mattar, 2009, p180). In Singaporean country music, for example, musicians should connect with their audiences and play as common as an old shoe, in order to be deemed authentic. They try to write their lyrics in a personalized way. It is quite necessary to link their songs to their audiences, so that the musicians' songs resonate with them. In addition, country music in Singapore will be seen as inauthentic if it has not been influenced by commercialization, or if the scene that they are trying to present, such as a rural area, clothing styles, or performance is not associated with the genre.

Singaporean music is always being regarded as "inauthentic." Even though Singaporean music is localized and is more accessible for locals, it still cannot resist the impact of Western music (such as British and American music). As Matter (1999) found, African-American jazz is always seen as authentic; as a result, Singaporean jazz will often be seen as just a version or a part of AfricanAmerican jazz. Because African-American jazz is seen as the original and authentic type of jazz, Singaporean jazz is usually regarded as derivative and unoriginal. In addition, African-American jazz also provides a sense of stylistic superiority compared to other forms of jazz music, including Singaporean jazz.

Hip-hop is one of the most popular and well-known music genres. As Armstrong (2004) argues, originality, pride in a local area, and a connection to original hip-hop music are the three decisive elements to judge whether hip-hop music is authentic. For example, Jay-Z, a worldfamous hip-hop artist from Brooklyn, writes his own lyrics, which could be identified as authenticity. Two of his songs actually refer to his hometown of Brooklyn: "Brooklyn's Finest" and "Brooklyn Go Hard." This directly gives his audiences the feeling of associating with East Coast hip-hop, which is where hip-hop first originated and evolved. Therefore, Jay-Z's hip-hop songs will always be regarded as authentic.

On the contrary, hip-hop songs from Singapore are barely connected to the original hip-hop culture. Most 
Singaporean hip-hop songs are produced in English and other Asian languages, such as Mandarin, Malay, and Tamil. The earliest hip-hop song released in Singapore was from a group called Kopi Kat Klan (Aripin, 2007). The first Singapore hip-hop song released by them contained examples of Singaporean identity, which could not be related to the origins of hip-hop music. In addition, the use of "Singlish," in most Singaporean hip-hop could make it feel distinct from original American hip-hop.

Singapore music can be defined as highly influenced by other types of music (such as: American music, British music, etc.) from all around the world and insert local cultures into the music production, for instance: combine local Chinese and Malay cultures with English language in music and western music tune. Thus, Singaporeans prefer popular Western music to their own music because of the language used in the songs (such as English, rather than Singlish) and their typical characteristics (such as: African-America music, East-coast hip-hop and so on) presented by the music which make people feel authenticity. In addition, they also regard Western culture as superior to theirs. Mattar (2009) argues that "Englishlanguage Singaporean musicians usually feel [that they are at the] 'fringe' of the music industry, because Western culture is superior to those of their former colonies." (p 181)As a result, a large number of Singaporean musicians have begun to switch from creating English songs to Malay or Mandarin songs, because they think that doing so could make them more successful and be more profitable. English has also been injected into other Asian music industries, such as that of South Korea, in which people regard English lyrics as crucial elements of hiphop and rap music. The deeply rooted reason for this is to target the global market and better express the meaning of song lyrics (Jin \& Ryoo, 2012).

\section{Media industry and its influences}

English song production in Singapore actually has a historical problem, through which musicians want to be "superior" and more accepted by local people because of the inferior position of Singlish songs in Singapore. It is quite a common idea that Singaporean English songs are usually regarded as inauthentic because of the stereotype that Singaporean music is inferior. Singaporeans often overlook domestic music and are sometimes skeptical about the quality of Singaporean English musicians. For instance, in the Singaporean recording industry, most people think that consumers will not support local musicians. It is ironic that Singaporean music is more popular in other Asian countries, such as Malaysia and Indonesia. This does not mean that Singaporean musicians are not good, just because society deems their local music to be inauthentic and even inferior to Western music, so that no market for Singaporean English-musicians can exist. These stereotypes or obstacles that Singaporean musicians encounter have still not been eliminated, and Singaporeans still tend to prefer Western music.

The situation of localized music in Singapore actually contrasts that of local music in other areas. For instance, in modern society, hip-hop music gives people a platform from which to present their own identity and illustrate and express their local identity; it is not solely for African-Americans. Some hip-hop artists from other countries have created their own genres of hip-hop music that have become accepted by both local and worldwide audiences, such as East Coast hip-hop, battle rap, and conscious rap. As Pennycook (2009) mentions that there are five decisive elements of why hip-hop music could easily adaptable to other cultures, there are graffiti, DJ-ing, break-dancing and MC-ing and knowledge. These five elements lead the hip-hop music become localized from global form and create some connections between the original hip-hop music and localized hip-hop music.

The government of Singapore sometimes plays an important role in local music production. In addition, the government always uses local broadcasting companies to promote patriotic songs and thereby, build a "stereotype" view for local music and make people feel "inauthenticity". Most of Singaporean media are controlled by the government, so it is quite easy for the government to promote patriotic songs. In the local music industry, Singaporean music is sometimes regarded as being supported by the government because many well-known, popular songs that are often transmitted by the national media system are nationalistic. Therefore, people sometimes feel confused about what real Singaporean music is because they may regard nationalistic songs as the real music and overlook the local musicians. According to Kong (1995), after 1988, the Singaporean government tried to use music to transmit Singaporean values and identity, in a program called "Sing Singapore." Music was used as a propaganda tool to transmit political policies and rules throughout Singapore. Thus, a large number of songs were recorded by organizations that were supported by the government. Under the influence of the Sing Singapore program, a number of musicians started to create nationalistic songs, such as "Count on Me, Singapore" by Hugh Harrison. The large number of patriotic songs released in the local market led to a stereotype of Singaporean music as being inauthentic.

Singaporean music combines many genres of music together, rather than having one music genre with high reputation and recognition. When people mention Singaporean music, it is hard to image a certain type of music that Singaporean musicians really excel at. For instance, there is no equivalent to British punk music, Jamaican reggae, or African-American hip-hop. Singaporean music only could be recognized as combine other genres of music and highly influenced by western music culture. Singapore cannot have its own type of music until its stereotypes and skeptical attitudes are eliminated. To a certain degree, the stereotype of Singaporean music rejects the possibility of creating a real Singaporean music which could become a heritage and become as an obstacle that local musicians must to face. This situation of overlooking local music tends to result in many different music genres entering and succeeding in the Singaporean music industry. For example, Japanese pop (J-pop) music caused a huge boom in Singapore. The mainstream media tried to promote J-pop, and Singaporeans became infatuated with it. According to $\mathrm{Ng}$ (2003), "one-quarter of households in Singapore who subscribed to cable chan- 
nels were exposed to J-pop." (p 11)Music from other countries quickly becomes popular in Singapore, yet the mainstream media never puts much effort into promoting localized music.

The judgment of authenticity could refer to four aspects: ethnic and cultural identity, group membership, status identity, and technologically mediated authenticity (Peterson, 2005). The initial purpose of branding Singaporean music as inauthentic was because it is not from American culture or not from an African-American who can perform hip-hop very well. It has same situation with other music genres, such as country music, punk, rock and roll, etc. Singaporean music is far away from the authentic music for a long period, because the local music is highly influenced by western music and thereby, losing originality and creativity. The high reputations of original music genres have led to overlooked performances and the similar music genres of Singaporean musicians. Singaporean music is sometimes greatly influenced by music from outside this small country, and few Singaporean musicians are recognized throughout the world. No one has actually admitted that Singapore could be a music production center, rather than as a main center for different music genres. As a result, the status and identity of Singaporean music is judged to be inauthentic. Technology has also played a decisive role in determining the inauthenticity of Singaporean music, as the Singaporean media spends much more time promoting Western music, while overlooking local music. For example, there is no specific TV program which promotes local music in TV Channel 8. Most of the music TV program in this channel is trying to introduce some popular songs from Billboard (such as: Hot 100 songs and Billboard 200). The reason is that it could attract more attention from audiences and local people prefer western music than Singaporean music. To some extent, people are easily influenced by the media and may regard Western music as authentic - this is technology determinism, which can actually control or drive the development of society's values and context.

\section{Conclusion}

In conclusion, the multicultural society of Singapore has created a great platform on which musicians from all around the world can perform. The process of globaliza- tion and Americanization has affected the development of local musicians, not only by capturing the local market, but also by changing people's perspectives about Singaporean music. Singaporean people assess their localized music differently from how they assess Western music. As Mattar (2009) says, "Singaporean music is perceived as 'B-list' product nowadays." (p 180) The use of Singlish in music production has created a feeling of inauthenticity among local people, which has resulted in giving little support to Singaporean musicians. The Singapore government's propaganda program has also created a stereotype that most Singaporean music has strong governmental backgrounds and contains nationalistic elements. Singapore lacks a real music genre that could represent the country make its people proud.

\section{References}

1. Jin, D. Y. \& Ryoo, W. Critical interpretation of hybrid K-pop: The global-local paradigm of English mixing in lyrics [J]. Popular Music and Society, (ahead-of-print), 2012, 1-19.

2. Kong, L. Popular music and a "sense of place" in Singapore [J]. Southeast Asian Studies, 1995, 9(2): 51-77.

3. Kong, L. Popular music in Singapore: Exploring local cultures, global resources, and regional identities [J]. Environment and Planning D: Society and Space, 1996, 14(3):273.

4. Mattar, Y. Habituation and choice in the process of consumption: a case study of popular music in Singapore [J]. Asian Studies Review, 2007, 27(4):443461.

5. Mattar, Y. Popular cultural cringe: Language as signifier of authenticity and quality in the Singaporean popular music market [J]. Popular Music, 2009, 28(2):179-195.

6. Ng, B. W. M. Japanese popular music in Singapore and the hybridization of Asian music [J]. Asian $\mathrm{Mu}$ sic, 2002, 34(1):1-18.

7. Pennycook, A. Global English and transcultural flows [J]. Routledge, 2007.

8. Peterson, R. A. In search of authenticity* [J]. Journal of Management Studies, 2005, 42(5):1083-1098. 